\title{
Cytotoxic and Antimicrobial Efficacy of Silver Nanoparticles Synthesized Using a Traditional Phytoproduct, Asafoetida Gum
}

This article was published in the following Dove Press journal: International Journal of Nanomedicine

\author{
Sandhanasamy Devanesan (iD) ${ }^{1,2}$ \\ Karuppiah Ponmurugan (iD ${ }^{3}$ \\ Mohamad S AISalhi ${ }^{1,2}$ \\ Naif Abdullah Al-Dhabi ${ }^{3}$ \\ 'Research Chair in Laser Diagnosis of \\ Cancer, Department of Physics and \\ Astronomy, College of Science, King Saud \\ University, Riyadh, Saudi Arabia; \\ ${ }^{2}$ Department of Physics and Astronomy, \\ College of Science, King Saud University, \\ Riyadh, Saudi Arabia; ${ }^{3}$ Department of \\ Botany and Microbiology, College of \\ Sciences, King Saud University, Riyadh \\ I I45 I, Saudi Arabia
}

Correspondence: Mohamad S AISalhi Research Chair in Laser Diagnosis of Cancer, Department of Physics and Astronomy, College of Science, King Saud University, Riyadh, Saudi Arabia

Email malsalhi@ksu.edu.sa
Purpose: The present study synthesized silver nanoparticles (AgNPs) using the aqueous extract of a traditional medicinal product consisting of an oleoresin (a combination of macromolecules of carbohydrates and proteins) exuded from the rhizome of the plant Ferula foetida (asafoetida gum) and evaluated its biological properties.

Materials and Methods: The silver nanoparticles synthesized using asafoetida gum (AsAgNPs) were characterized using UV/Vis spectroscopy, fourier infrared (FTIR) spectroscopy, scanning electron microscopy (SEM) with energy dispersive X-ray analysis (EDX), X-ray diffraction (XRD) and transmission electron microscopy (TEM) and EADX. The cytotoxicity and antimicrobial activity As-AgNPs were evaluated against MCF-7 cell lines and selected microbial pathogens, respectively.

Results: The synthesized silver nanoparticles were crystalline in nature with a spherical shape. The average particle size was $5.6-8.6 \mathrm{~nm}$. The cytotoxicity of the synthesized AsAgNPs was evaluated against MCF-7 cell lines, and the As-AgNPs were found to be effective in inhibiting the multiplication of cancer cells. The As-AgNPs exhibited significant antimicrobial activity towards E. coli, $K$. pneumoniae and C. albicans. The MIC of the synthesized As-AgNPs was $7.80 \mu \mathrm{g} / \mathrm{mL}$ for E. coli ATCC 25922, Salmonella sp. WS50- and S. typhi; $15.60 \mu \mathrm{g} / \mathrm{mL}$ for $S$. typhimurium and $S$. aureus $\mathrm{WS} 10$, and $31.20 \mu \mathrm{g} / \mathrm{mL}$ for $K$. pneumoniae and $S$. aureus ATCC 43300-MRSA. In addition, MIC values of $15.60 \mu \mathrm{g} / \mathrm{mL}$ for C. albicans ATCC8436 and $31.20 \mu \mathrm{g} / \mathrm{mL}$ for C. krusei ATCC6258 were obtained.

Conclusion: As asafoetida is a good traditional medicine, its involvement in the synthesis of AgNPs led the silver nanoparticles to exhibit good cytotoxic and antimicrobial effects.

Keywords: asafoetida gum, AgNPs, antimicrobial, cytotoxicity, biomedical agent

\section{Introduction}

Asafoetida is the dried latex extruded from the rhizome of a perennial herb, Ferula foetida. Traditionally, asafoetida gum is used for digestive benefits and is a kitchen consumable in many South Indian homes. It gives a pleasant flavor to foodstuffs and is a good antioxidant, with antimicrobial and anticancer properties. ${ }^{1}$ The prime constituents of asafoetida latex include resin (above 60\%), endogenous gum (above $20 \%$ ), volatile oil (above 15\%) and ash (less than 10\%). Asafoetida has been used as a sedative agent for neuropathic patients because it induces sleep without any adverse effects. $^{2,3}$ Asafoetida latex extract has been reported to reduce serum cholesterol and blood pressure. ${ }^{4}$ Recently, asafoetida in combination with other organosulfur compounds was reported to stimulate neutrophil activities. It is 
capable of altering the biological response process by increasing phagocyte roles. ${ }^{5}$ Asafoetida gum has been reported as a reducing agent for neurological diseases, and it reduces the oxidative stress marker malondialdehyde and increases superoxide dismutase in brain tissue. ${ }^{6}$ Ethanol extract of asafoetida gum has been shown to enhance insulin secretion and to reduce fasting sugar levels in Wistar rats, and it functions as a hypoglycemic and hypolipidemic agent. ${ }^{7}$ Chinese physicians use asafoetida extract to treat heart diseases. ${ }^{8}$ Asafoetida is used for many respiratory ailments, including H1N1 swine flu. In folk medicine, it is used as a remedy for many purposes, including to provide carminative, antispasmodic, expectorant, sedative, diuretic and many other effects.

An antimicrobial study carried out using asafoetida extracts showed good inhibitory action towards both Gram-positive and Gram-negative bacterial pathogens. ${ }^{9}$ The bioactive compounds isolated from asafoetida were tested against nosocomial infections, and the result showed that the bacterial strains that were resistant to drugs responded well, confirming the antimicrobial potential of the isolated compounds. ${ }^{10}$ The toxicity of AgNPs has become a controversial because the molecular mechanism of nanosilver is focused on the surface, it can be easily oxidized by $\mathrm{O}_{2}$ and several molecules in the environmental and biological systems due to the release of $\mathrm{Ag}+$. The toxicity is mostly related to the release of toxic ion (Ag $+){ }^{11}$ The surface oxidation rate is closely related to the nanosilver surface coating of coexisting molecules like thiol derivatives and to assist the right environments. The nanosilver can be capable to interact with nucleic acids, lipid molecules, and proteins; further, it also penetrates into the cell and also incorporates within a biological system. The nanosilver can cause oxidative stress via ROS and damage the complex biomolecules system including DNA, enzymes, proteins and cell membranes. ${ }^{12}$

The cytotoxicity effects of asafoetida resin have been reported in NB4 and HL-60 cell lines, and asafoetida resin induced apoptosis in cancer cell lines without affecting normal cell lines. Furthermore, no toxic effects were recorded even at high doses. ${ }^{13}$ Another study on the cell viability of HeLa cells by using F. gummosa extracts revealed dose- and time-dependent action as a radiosensitizer agent in cervical cancer. ${ }^{14}$ The compounds isolated from asafoetida gum exhibited good cytotoxic effects in HepG2, Hep3B, and MCF-7 cancer cell lines. ${ }^{15}$
The selection of reducing agents is very important in the field of green synthesis of silver nanoparticles. The chemical reduction method is one of the ideal and widely used methods with a variety of organic and inorganic reducing agents. The medicinal plant extract was used for the synthesis of silver nanoparticles which consist of various reducing agents like phenolic, polyphenols and flavonoid compounds. ${ }^{16}$ In addition, alkaloids, proteins, amino acids, alcoholic compounds, and polysaccharides are act as reducing agents during the synthesis of nanoparticles. The reduction reactions of silver ions into silver nanoparticles were completed with reducing agents. ${ }^{17}$ The current study aimed to synthesize silver nanoparticles (AgNPs) using aqueous extracts of asafoetida gum and to evaluate their antibacterial, antifungal and cytotoxic effects. Information on the synthesis of AgNPs using asafoetida gum is scant in the literature. Hence, the present study was designed to elucidate its role in nanomedicine.

\section{Materials and Methods Preparation and Synthesis of Asafoetida (As)-AgNPs}

Asafoetida is an oleoresin exuded from the rhizome of the plant Ferula foetida. Five hundred grams of asafoetida gum was purchased from a supermarket in the Riyadh region of Saudi Arabia. The sample was washed with tap and distilled water to remove unwanted fine particles and allowed to dry. The gum was ground into a fine powder. Twenty-five $\mathrm{mg}$ of the fine powder was dissolved in $500 \mathrm{~mL}$ of Milli Q water and filtered. The filtrate was designated as the aqueous extract of asafoetida and was used for further experiments.

To prepare silver nitrate nanoparticles, $84.94 \mathrm{mg}$ of silver nitrate $(1 \mathrm{mM})$ was dissolved in $500 \mathrm{~mL}$ of Milli Q water, to which $20 \mathrm{~mL}$ of freshly prepared asafoetida extract was added. The reaction mixture was monitored, and the pale yellow reaction mixture became brown in 24 $\mathrm{h}$. The colored mixture was centrifuged at $18000 \mathrm{rpm}$ for $15 \mathrm{~min}$ and then washed. The process was repeated three times. The sediment obtained was dried in a vacuum evaporator. The dried powder was designated as AsAgNPs and stored for further study.

\section{Characterization of As-AgNPs UV-Vis Spectroscopy}

UV-Vis spectroscopy (PerkinElmer LS 40, USA) was used to evaluate the reduced state of AgNPs in an optical density range of 200 to $800 \mathrm{~nm}$. 


\section{Attenuated Total Reflection (ATR)}

The total reflectance of As-AgNPs was measured by ATR spectroscopy using a Perkin Elmer instrument (USA). ATR was used to measure the active constituents in the synthesized materials, and the scanning range was $4000-650 \mathrm{~cm}^{-1}$.

\section{X-Ray Diffraction (XRD)}

The XRD patterns of the synthesized particles were observed using an X-ray diffractometer operated at 40 $\mathrm{kV}$ with $2 \theta$ values from 20 to 50 . The results were compared with the JCPDS library to confirm the crystalline nature of the AgNPs.

\section{AgNP Size and Shape Measurements}

TEM investigation was carried out by using a JEM-1230 (JEOL, Tokyo, Japan) with high resolution to measure the particle shape, size and distribution. In addition, SEM and EDS analyses were performed in our earlier studies to determine the size and element distribution. ${ }^{18-20}$

\section{Cytotoxicity Assessments and Morphological Study}

An MTT assay was performed following the method of Mosmann et $\mathrm{al}^{21}{ }^{21}$ with certain modifications. The MCF-7 cell line obtained from ATCC was grown in DMEM medium, asafoetida gum supplemented with fetal bovine serum (FBS) $(10 \%)$, sodium bicarbonate $(0.2 \%)$, and antibioticantimycotic solution $(1 \mathrm{~mL} / 100 \mathrm{~mL}$ of medium). In brief, MCF-7 cells (10000 in number) were seeded into 96-well tissue culture plates and incubated overnight in a $\mathrm{CO}_{2}$ incubator. Then, the medium was aspirated and replaced with medium containing different concentrations $(1-100 \mu \mathrm{g} / \mathrm{mL})$ of synthesized nanoparticles. The cells were treated for $24 \mathrm{~h}$ in the nanoparticle medium. Then, MTT reagent $(10 \mu \mathrm{L} /$ well containing $100 \mu \mathrm{L}$ of cell suspension; $5 \mathrm{mg} / \mathrm{mL}$ stock in PBS) was added to each well and incubated for $4 \mathrm{~h}$ at $37^{\circ}$ C. After that, the reaction mixture was carefully removed, and $200 \mu \mathrm{L}$ of DMSO was added to each well by pipetting up and down several times until the content was homogenized. After $10 \mathrm{~min}$, the color was read at $550 \mathrm{~nm}$ using a UV-Vis spectrophotometer. An untreated control was also run simultaneously under identical conditions.

To study morphological changes, MCF-7 cells were exposed to different concentrations $(1-100 \mu \mathrm{g} / \mathrm{mL})$ of nanoparticles for $24 \mathrm{~h}$. Then, the nanoparticle-induced morphological changes in the cells were observed under a phase-contrast inverted microscope. The cell images were collected at $20 \mathrm{x}$ magnification.

\section{Microbial Pathogens}

The bacterial pathogens selected for the current investigation were acquired from IMTECH (MTCC), Chandigarh and ATCC (Manassas, USA). The microbial isolates were Staphylococcus aureus ATCC 43300 (MRSA), Enterococcus faecium VR 83,198 (VRE), Staphylococcus aureus WS 10, Escherichia coli ESBL 937316, Escherichia coli ATCC 25922, Salmonella typhi WS 03, Salmonella typhimurium ATCC 14028, Salmonella sp. WS 50, Acinetobacter baumanni MDR 4414 and Klebsiella pneumoniae ATCC 700603. The fungal pathogens included Candida albicans ATCC 8436, Candida krusei ATCC 6258 and Candida parapsilosis ATCC 22019. All the cultures were periodically subcultured and maintained in potato dextrose agar (PDA) medium.

\section{Preparation of Microbial Inoculums}

One loop of bacterial culture was collected from the bacterial cultures, which were grown on nutrient agar slants, and inoculated into $10 \mathrm{~mL}$ of nutrient broth. Then, the broth culture was incubated for $18 \mathrm{~h}$ at $37^{\circ} \mathrm{C}$. The culture obtained was used as inoculum for the sensitivity bioassay. The final bacterial inoculum size was used standard 0.5 McFarland (1 $\mathrm{X} 10^{8} \mathrm{CFU} / \mathrm{mL}$ ) concentrations. The fungi were cultured on Sabouraud dextrose broth (SDB) slants at $30^{\circ} \mathrm{C}$ for $24 \mathrm{~h}$ and the final inoculum size was $2 \times 10^{6} \mathrm{PFU} / \mathrm{mL}$.

\section{Antimicrobial Activity}

The antibacterial activity of the asafoetida-mediated silver nanoparticles (As-AgNPs) was tested by the agar diffusion method as described by Bonev et al. ${ }^{22} \mathrm{~A}$ total of $0.1 \mathrm{~mL}$ of bacterial or fungal culture was seeded on Mueller-Hinton agar (MHA) plates. Six-mm-diameter wells were made on the MHA plates with a steel-core borer, and then the wells were loaded with 15,25 and $50 \mu \mathrm{L}$ of the As-AgNPs. Streptomycin (10 mcg), nystatin (50 mcg), and DMSO (1 $\mathrm{mL}$ ) were used as positive and negative controls. The bacterial and fungal culture plates were incubated at $37^{\circ}$ $\mathrm{C}$ and $30^{\circ} \mathrm{C}$ for $18 \mathrm{~h}$ and $24 \mathrm{~h}$, respectively. After incubation, the zone of inhibition was measured, and the values were recorded.

\section{Minimal Inhibitory Concentration (MIC) Determination}

The minimum inhibitory concentrations (MICs) of the As-AgNPs were evaluated using the microdilution method described by Bonev et al. ${ }^{22}$ Briefly, the AsAgNPs were dispersed in DMSO and sterile distilled water at a ratio of 20:80. The MIC was determined by 


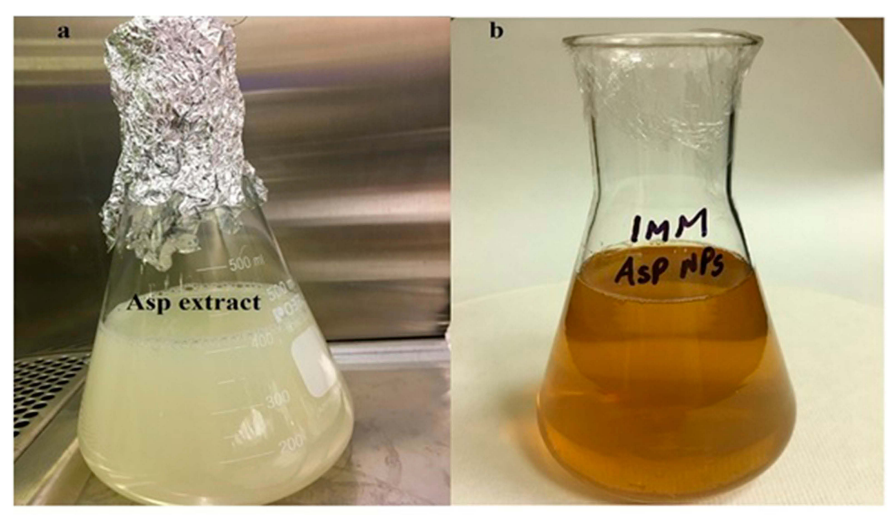

A

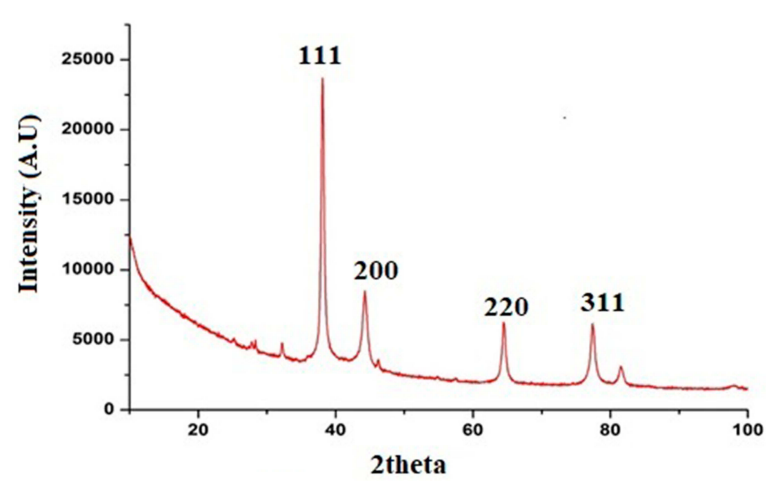

C

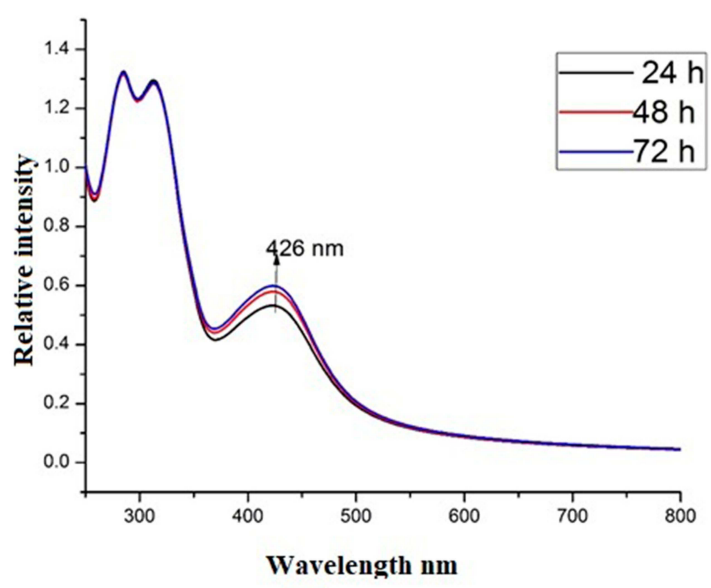

B

Figure I Asafoetida gum extracts, (A) representative before formation nanoparticles asafoetida gum extracts (B) silver nanoparticles formed after reaction of asafoetida gum extracts with I mM of silver nitrate (C) UV-Vis spectrum of As-AgNPs at $426 \mathrm{~nm}$ with different time intervals (24-72 h).

using 96-well microtiter plates. The total mixture contained $185 \mu \mathrm{L}$ of nutrient broth, $10 \mu \mathrm{L}$ of As-AgNPs and $5 \mu \mathrm{L}$ of the log-phase culture of microbial pathogens. The suspension was mixed completely and diluted two-fold before adding the bacterial pathogens. Finally, $5 \mu \mathrm{L}$ of the microbial pathogens were loaded

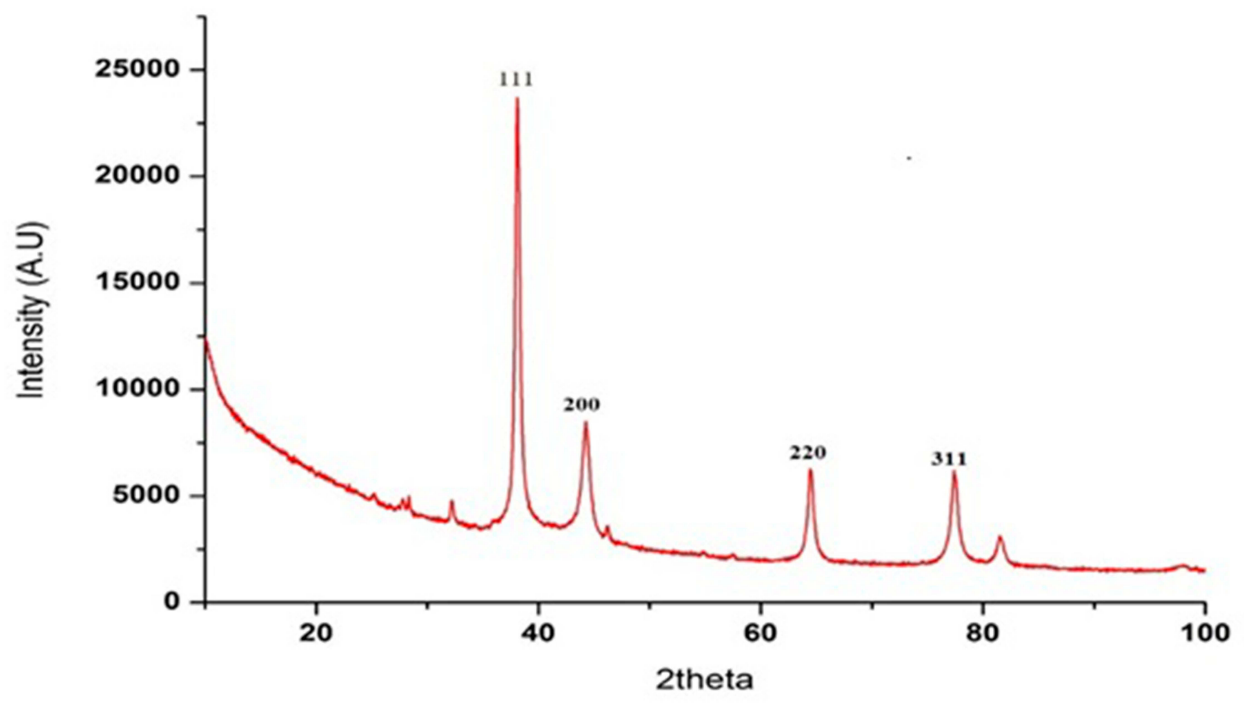

Figure 2 X-ray diffraction pattern of silver nanoparticles synthesized using As-AgNPs. 


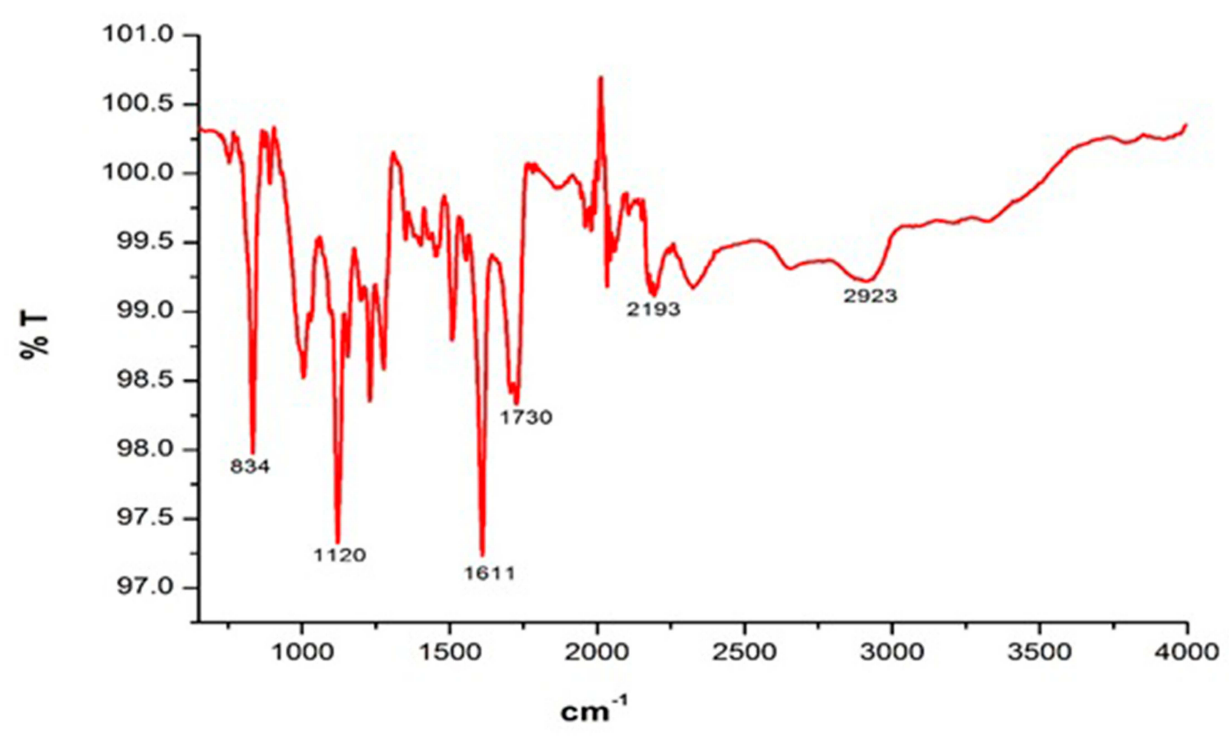

Figure 3 The ATR-IR spectrum of synthesized As-AgNPs.

into each well and mixed thoroughly. Subsequently, the microtiter plates were incubated for $24 \mathrm{~h}$ at $37^{\circ} \mathrm{C}$, and streptomycin was used as a positive control. The microtiter plates were observed for bacterial growth after incubation.

\section{Statistical Analysis}

The results were analyzed by using the software Graphpad InStat 6.0. The mean $\pm \mathrm{SD}$ and $\mathrm{EC}_{50}$ values were determined, and the values were compared by using one-way
ANOVA. Data are expressed with a significance level of $\mathrm{p}<0.05$.

\section{Results and Discussion} Biosynthesis and Characterization of AsAgNPs

The asafoetida gum aqueous extract was light yellow in color (Figure 1A and B), and upon the addition of colorless $\mathrm{AgNO}_{3}$ solution, the color of the mixture turned dark brown due to surface Plasmon resonance (SPR) within 24

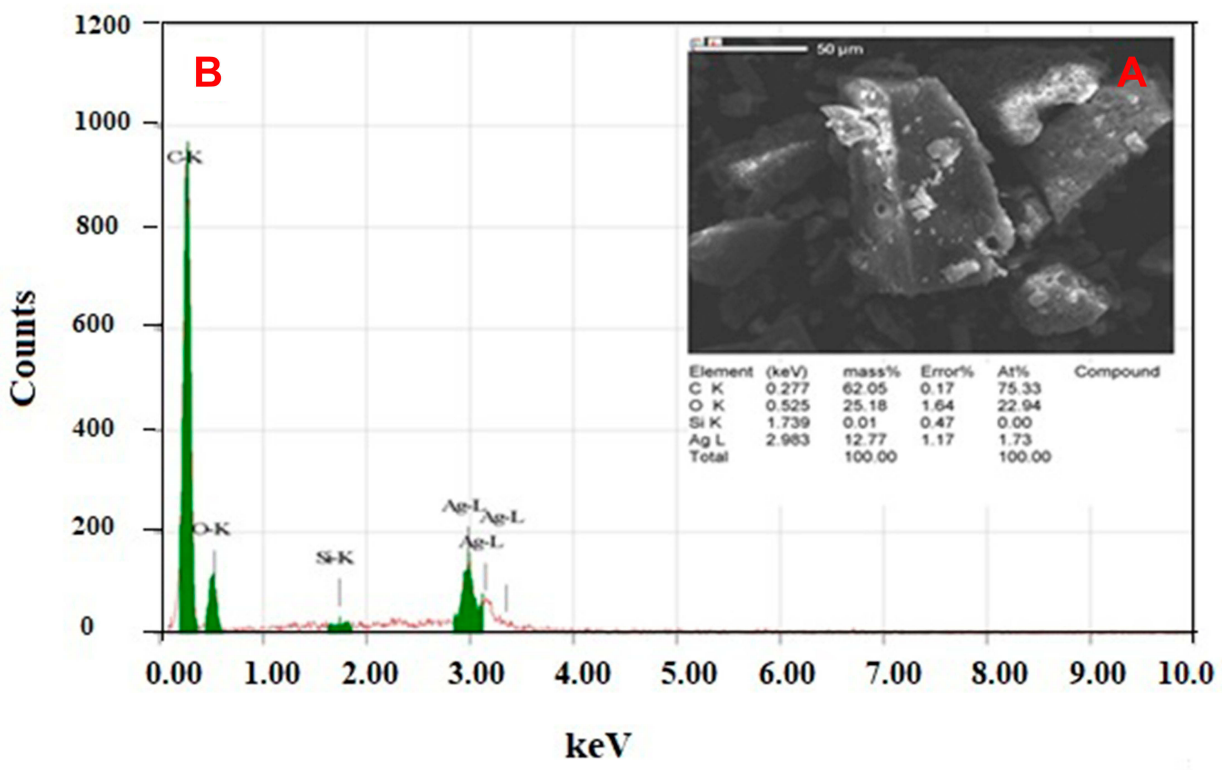

Figure 4 (A) SEM image of synthesized As-AgNPs, (B) distribution of elements analysis from As-AgNPs by EADX. 
$\mathrm{h}$, indicating the formation of silver nanoparticles. A strong absorption peak was observed in the UV-Vis absorption spectrum at $426 \mathrm{~nm}$ at different time intervals (24-72 h) (Figure 1C). The peak was due to the large number of molecules that were widely dispersed in the mixture solution, confirming our previously reported results. ${ }^{18-20}$ The stability of synthesized As-AgNPs was assessed with the same experimental protocol repeated. The synthesis process was monitored by visual observation by the change of color and agglomeration within a period of time (24-72 h). The synthesized As-AgNPs were characterized with UV-Vis spectroscopy to evaluate stabilization and recorded the same absorption peak at $420 \mathrm{~nm}$. The observed result has confirmed the stability of synthesized As-AgNPs.

The XRD patterns of the formed nanoparticles showed four distinct diffraction peaks, and Braggs reflections were observed in the XRD patterns at $2 \theta=38.90,44.26,64.43$ and 77.38. The corresponding values were 111, 200, 220 and 311, respectively, indicating the crystalline nature of the Ag NPs (Figure 2). The results were compared with the JCPDS library [JCPDS No. 04-783], and the results revealed the high purity of the Ag NPs, according to previous literature. ${ }^{18-20}$

The properties of the synthesized As-AgNPs were studied by using ATR-IR spectroscopy (Figure 3). The IR spectrum bands at 2923, 2193, 1730, 1611, 1120 and $834 \mathrm{~cm}^{-1}$ further confirmed the properties of the silver nanoparticles. The IR spectral peaks confirmed that the silver ions were incorporated with asafoetida gum, as

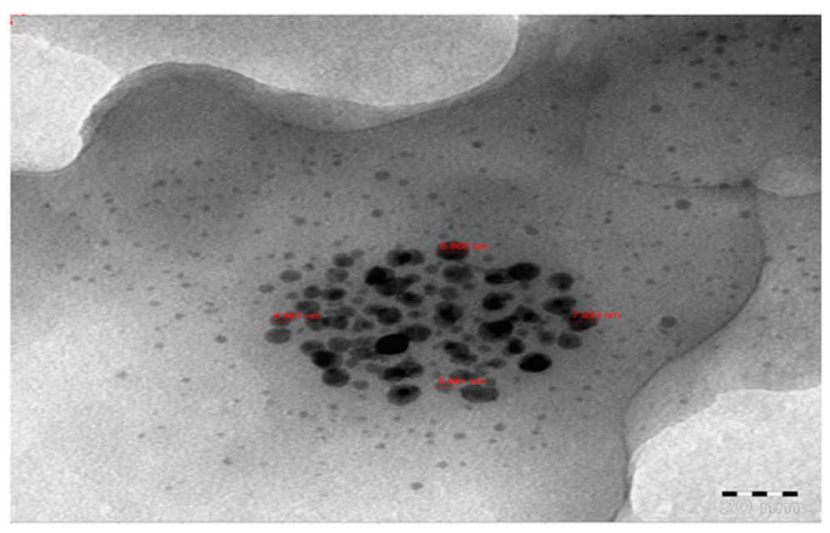

Figure 5 TEM images of synthesized As-AgNPs with JEM-I 230 and showing the shape, size and distribution of NPs.

indicated by the presence of hydroxyl and carboxyl groups. ${ }^{23}$

SEM analysis was performed to visualize the size and shape of the silver nanoparticles. SEM images of the AsAgNPs are given in Figure 4A. The SEM results revealed that the average size was $5.60-8.66 \mathrm{~nm}$ with inter-particle dispersion. The differently shaped AgNPs were used as capping agents in the asafoetida gum extract. The EDX results showed evidence of the presence of $\mathrm{Ag}$ in the asafoetida gum-mediated nanomaterial (Figure 4B). The data obtained showed distinct spherical poly-dispersed AgNPs with a small size and without significant agglomeration. Such small nanoparticles have an enhanced surface area, thereby promoting good reactivity and catalytic properties. ${ }^{24}$ Particle size enhances nanoparticle interactions in necrotic tissues via vascular gaps in cancerous
A

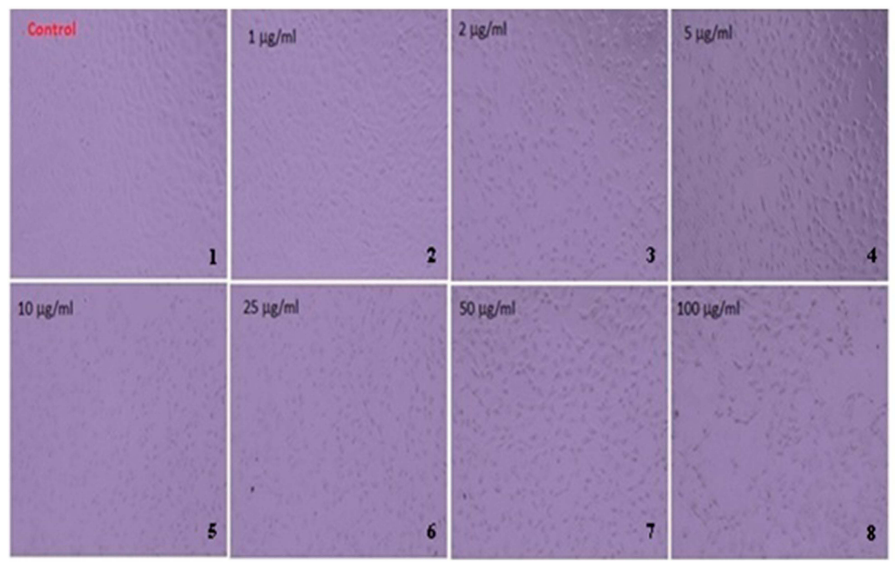

B

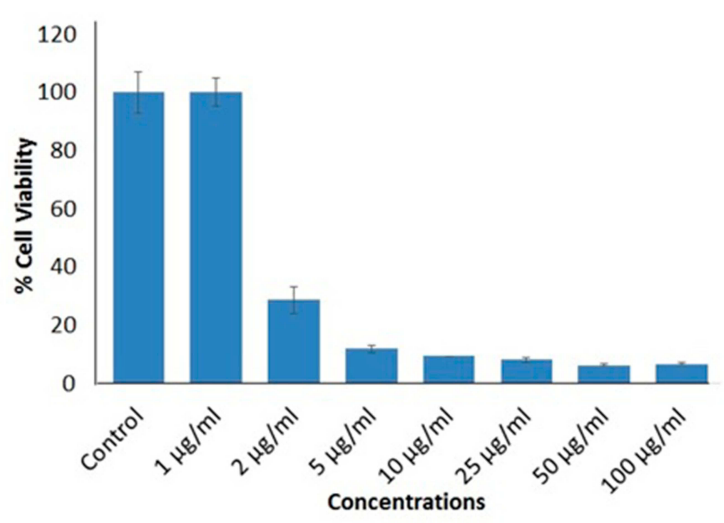

Figure 6 (A) Morphological changes of MCF-7 tumor cell lines, images with phase-contrast microscope (20X) changes of cell lines towards different concentrations of AsAgNPs, (B) Viability of MCF-7 tumour cell line on exposure to different concentrations of As-AgNPs. 
cells. ${ }^{25}$ The enhanced permeability and retention (EPR) effect due to the small size of nanoparticles helps in the high accumulation of NPs in tumor areas. ${ }^{26,27}$ Green synthesized NPs contain several active compounds, which enhance the bioactivities of these NPs. Scavenging activities have been observed in AgNPs prepared using different natural polyphenols, such as epigallocatechin-3gallate, resveratrol, and fisetin. ${ }^{28}$

The TEM analyses focused on the morphology and particle size distribution profile of the formed As-AgNPs, as shown in Figure 5. The As-AgNPs have a spherical shape with an average size range of $5.0-7.8 \mathrm{~nm}$, which is in agreement with the SEM images. The data obtained showed distinct spherical polydispersed AgNPs with a small size and without significant agglomeration. Such small nanoparticles have an enhanced surface area, thereby promoting good reactivity and catalytic properties. ${ }^{24}$

\section{Cytotoxicity Activity of As-AgNPs}

The cytotoxicity effect of the nanoparticles synthesized using asafoetida extract on MCF-7 cells was studied using an MTT assay. The microscopic analysis confirmed the toxic effect of the synthesized AgNPs against MCF-7 cell lines (Figure 6A (1-8)). Morphological observations showed nuclear hypertrophy, cell shrinkage, nuclear condensation and fragmentation, apoptosis and cell death. The control cells showed intact nuclei and cytoplasm. The viability of the MCF-7 cell line against different doses showed that the AgNPs synthesized using asafoetida extract were able to inhibit cell viability to a great extent in a dose-dependent manner. The cytotoxicity effects of different concentrations of synthesized AgNPs under in vitro conditions on the MCF-7 cell line showed a maximum $\mathrm{IC}_{50}$ value of 2.0 $\mu \mathrm{g} / \mathrm{mL}$ (Figure $6 \mathrm{~B}$ ) and have not used any proven anticancer drug as a positive control. However, the cytotoxic responses of nanoparticles were compared with the untreated control set of the cells.

The cytotoxic effect of the As-AgNPs indicates that the biosynthesized AgNPs can be used as chemotherapeutic agents. ${ }^{29}$ Green synthesized AgNPs reduced the surface attachment owing to reducing agents attached within the inner surface of $\mathrm{Ag}^{+}$and converted in lower size of molecules within 1-100 nm. It can provide information on cell death, survival, and metabolic activities during cytotoxicity analysis. The cytotoxic effects induced by the As-AgNPs at lower concentrations could be due to the plant components attached to the AgNPs. ${ }^{30}$
The results obtained from this study confirmed the cytotoxic effect of biosynthesized AgNPs, which has been reported in several studies. For example, the maximum number of cell death was observed in breast cancer MCF-7 cell line with lower concentration by NDAgNPs. ${ }^{31}$ Another study also confirmed that the lower concentration exhibited cytotoxicity oral fibroblasts used for A. muricata extract, ${ }^{32}$ The similar report suggested that the cytotoxicity of AgNPs depends on the dosedependent manner in MCF-7 cells by $S$. striata AgNPs. ${ }^{33}$ HeLa cell line using pomegranate leaf extract, Cannonball leaves AgNPs against MCF- $7^{34}$ and HCT8 used for plant seed extract AgNPs. ${ }^{35}$ Synthesized AgNPs with a large surface to volume ratio easily enter cells, interact with cell constituents, and interfere with cellular signaling pathways. AgNPs interact with mitochondria and affect cellular chain function. These interactions cause an increase in the ROS level, resulting in oxidative stress, as reported previously. ${ }^{36}$ The high cytotoxicity of AgNPs against cancerous cells is due to the high uptake of nanoparticles by cancer cells rather than healthy cells. Cancerous cells exhibit abnormal metabolism and a high proliferation rate, which in turn facilitate their vulnerability to AgNPs. ${ }^{37-39}$ Asafoetida is rich in polyphenols and flavonoids, and nanoparticles inspired by this material have rich antioxidant potential. ${ }^{1,2}$ The current AgNPs with polyphenols are involved in ROS and inhibit the transcription process. It is noteworthy that antioxidants such as polyphenols show cytotoxicity only against non-healthy cells. This behavior supports the observation that the nanoparticles exhibit concentration-dependent toxicity.

The antimicrobial activity of the synthesized silver nanoparticles was examined towards selected bacterial and fungal pathogens, and the zone of inhibition was compared to that obtained by using standard antibiotics. The bacterial pathogens included S. aureus VR83198 (VRE), S. aureus WS10, E. faecium ATCC 43300 (MRSA), E. coli ESBL937316, E. coli ATCC 25922, S. typhi WS03, S. typhimurium ATCC 700603, K. pneumoniae MDR 4414, Salmonella sp. WS50 and A. baumanni MDR 4414 (Table 1, Figure 7A); and the pathogenic yeast included $C$. albicans ATCC8436, $C$. krusei ATCC 6258 and C. parapsilosis ATCC22,019 (Table 1, Figure 7B). The zone of inhibition ranged between 7.00 and $15.00 \mathrm{~mm}$. However, the As-AgNPs did not inhibit E. faecium VR 83198, A. baumanni MDR 4414 or $C$. parapsilosis ATCC 22019. The As- 
AgNPs significantly inhibited the other microbes (Table 1). The present antimicrobial evaluation studies positively coordinated with reports of Sangeetha et al, ${ }^{40}$ and Mohammed et al. ${ }^{41}$

The MIC of the As-AgNPs was $7.80 \mu \mathrm{g} / \mathrm{mL}$ for $E$. coli ATCC 25,922 and $7.80 \mu \mathrm{g} / \mathrm{mL}$ for $S$. typhi WS03 and Salmonella sp. WS50, whereas the MIC for S. aureus WS 10 and $S$. typhimurium ATCC 14,028 was $15.60 \mu \mathrm{g} /$ $\mathrm{mL}$. Conversely, MICs of 250.00 and $500.00 \mu \mathrm{g} / \mathrm{mL}$ were observed against multidrug-resistant strains, viz., A. baumanni MDR 4414 and E. faecium VR 83198, respectively (Table 2).

The mechanism of the antimicrobial activity of AsAgNPs might interact with the microbial membrane, prominently to membrane damage, it will kill the bacteria. ${ }^{42}$ The As-AgNPs first attachment to the cell membrane and the interruption and release of cellular constituents, resulting in a loss of permeability. ${ }^{43}$ The antimicrobial activity could also be an interaction between small bacterial cells and AgNPs induce a metabolic imbalance in microbial cells after the assimilation of As-AgNPs, leads to the formation of intracellular reactive oxygen species that kills bacteria consequently. ${ }^{44}$

The antimicrobial effect of silver nanoparticles is dominated by their morphological characteristics and concentration. Smaller nanoparticles have the advantage of higher percentages of interactions when compared to larger particles. The smallest nanoparticles displayed maximum activity towards the microbial pathogens, despite being more prone to diffusion than larger particles. ${ }^{45}$ The antimicrobial efficiency of nanoparticles is also based on their shape. ${ }^{46}$ In particular, triangular nanoparticles have shown more significant inhibitory activity than spherical and rod-shaped AgNPs. ${ }^{47}$ In addition, the concentration significantly influences the antimicrobial activities of silver nanoparticles. For example, a 50 to $100 \mathrm{mg}$ of total silver content is required to reduce bacterial colony-forming units. The AgNPs were mainly extracellular, and the

Table I Zone of Inhibition in Diameter of As-AgNPs Against Selected Microbial Pathogens

\begin{tabular}{|c|c|c|c|c|}
\hline \multirow[t]{2}{*}{ Microbial Pathogens } & \multicolumn{2}{|c|}{ As-AgNPs } & \multicolumn{2}{|c|}{ Streptomycin (10 mcg) } \\
\hline & ZID@ & $\mathbf{\pm S D *}$ & ZID & \pm SD \\
\hline \multicolumn{5}{|l|}{ Gram positive } \\
\hline $\begin{array}{l}\text { Staphylococcus aureus } \\
\text { ATCC } 43300 \text { (MRSA) } \\
\text { Enterococcus faecium } \\
\text { VR } 83198 \text { (VRE) } \\
\text { Staphylococcus aureus WSI0 }\end{array}$ & $\begin{array}{l}7.0 \\
N D^{\$} \\
8.0\end{array}$ & $\begin{array}{l}0.65 \\
- \\
0.22\end{array}$ & $\begin{array}{l}R^{\#} \\
15.0 \\
20.0\end{array}$ & $\begin{array}{l}- \\
0.55 \\
1.0\end{array}$ \\
\hline \multicolumn{5}{|l|}{ Gram negative } \\
\hline $\begin{array}{l}\text { E. coli ESBL } 937316 \\
\text { E.coli ATCC } 25922 \\
\text { Salmonella typhi WSO3 } \\
\text { Salmonella typhimurium } \\
\text { ATCC } 14,028 \\
\text { Salmonella sp. WS50 } \\
\text { Acinetobacter baumanni } \\
\text { MDR 44I4 } \\
\text { Klebsiella pneumoniae } \\
\text { ATCC } 700603\end{array}$ & $\begin{array}{l}8.0 \\
12.0 \\
10.0 \\
9.0\end{array}$ & $\begin{array}{l}0.42 \\
1.0 \\
0.55 \\
0.64\end{array}$ & $\begin{array}{l}R \\
19.0 \\
16.0 \\
18.0 \\
17.0 \\
15.0 \\
18.0\end{array}$ & $\begin{array}{l}- \\
0.70 \\
0.35 \\
0.60 \\
0.52 \\
0.18 \\
1.0\end{array}$ \\
\hline \multicolumn{5}{|c|}{ Fungal pathogens Nystatin (50 mcg) } \\
\hline $\begin{array}{l}\text { Candida albicans ATCC } 8436 \\
\text { Candida krusei ATCC } 6258 \\
\text { Candida parapsilosis } \\
\text { ATCC } 22019\end{array}$ & $\begin{array}{l}9.0 \\
7.0 \\
\text { ND }\end{array}$ & $\begin{array}{l}1.0 \\
0.40 \\
-\end{array}$ & $\begin{array}{l}18.0 \\
14.0 \\
15.0\end{array}$ & $\begin{array}{l}0.85 \\
0.28 \\
0.40\end{array}$ \\
\hline
\end{tabular}

Abbreviations: ${ }^{@} \mathrm{ZID}$, zone of inhibition in diameter; *SD, standard deviation; ${ }^{\$} \mathrm{ND}$, not detected; ${ }^{\#} \mathrm{R}$, resistant. 


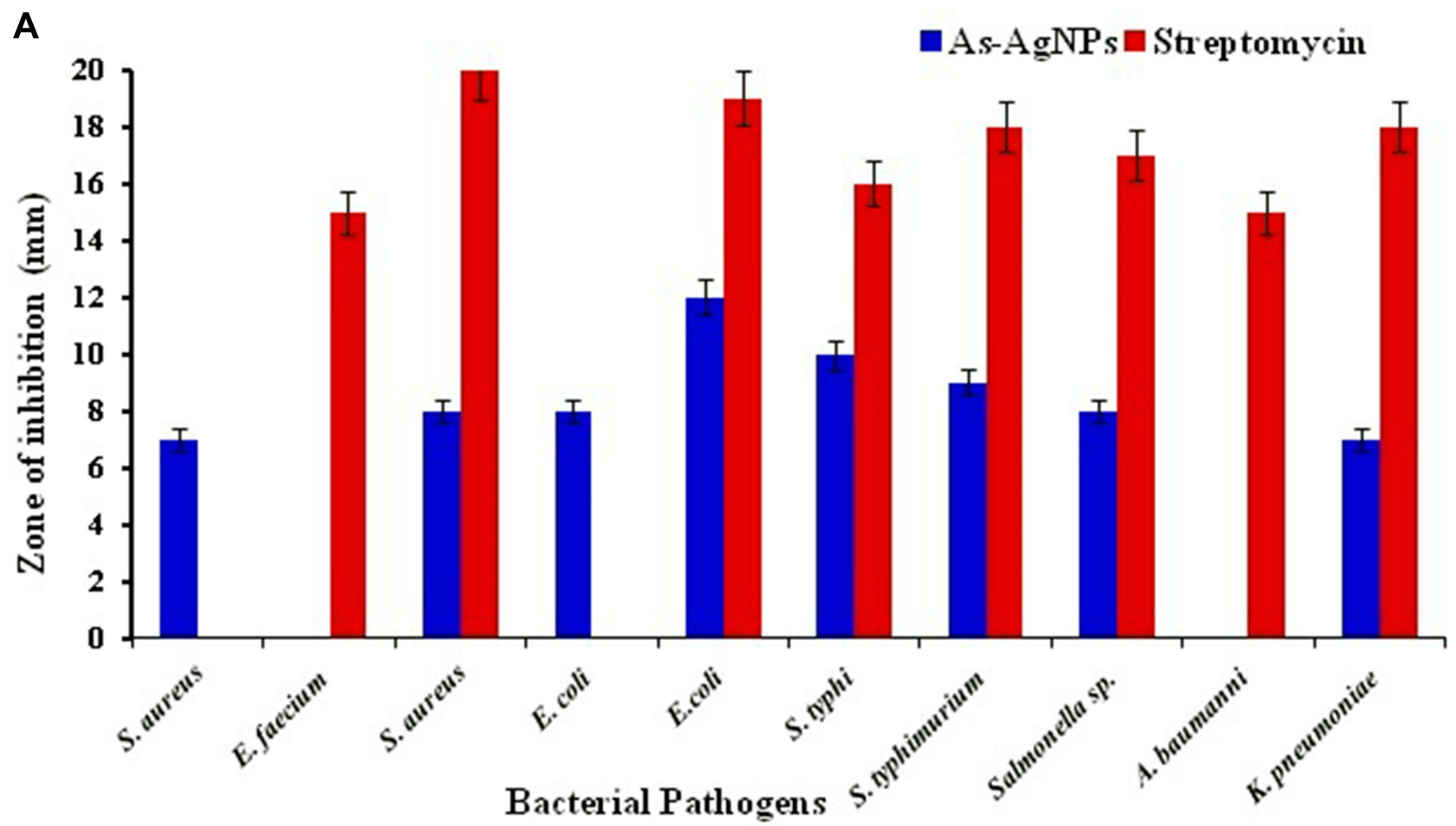

B

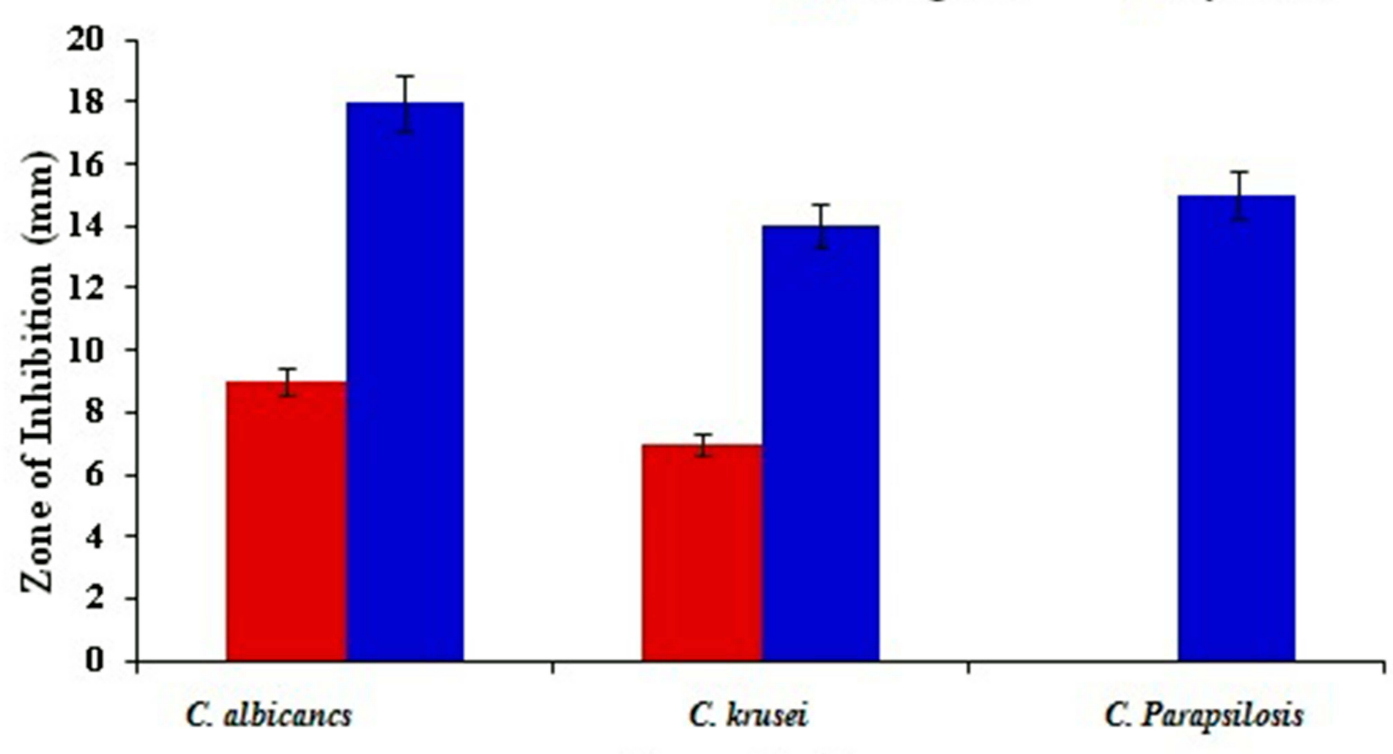

Fungal Pathogens

Figure 7 (A) Antimicrobial activity of As-AgNPs against selected bacterial pathogens, (B) Antifungal activity of As-AgNPs against fungal pathogens.

resulting nanoparticle size range was 5 to $100 \mathrm{~nm}$, specifically $10-50 \mathrm{~nm}$, with spherical shapes. ${ }^{18-20}$ The antimicrobial and antitumor potential of As-AgNPs demonstrates the comprehensive development of new antimicrobial particles with an improved antimicrobial mechanism against human microbial pathogens.
According to the objectives of our current work, the As-AgNPs were synthesized using Asafoetida with significant range and size. Further, the synthesized As-AgNPs were exhibited efficient cytotoxicity and antimicrobial activities against cell lines and microbial pathogens, respectively. These outcomes open a new way to the 
Table 2 MIC Value of as-AgNPs for Different Bacterial Pathogens

\begin{tabular}{|l|l|}
\hline Microbial Pathogens & MIC Values $(\mu \mathrm{g} / \mathbf{m L})$ \\
\hline Gram positive bacteria & \\
Staphylococcus aureus ATCC 43,300 (MRSA) & 31.20 \\
Enterococcus faecium VR 83I98 (VRE) & 500.0 \\
Staphylococcus aureus WSI0 & 15.60 \\
\hline Gram negative bacteria & \\
E. coli ESBL 937316 & 31.20 \\
E.coli ATCC 25922 & 7.80 \\
Salmonella typhi WS03 & 7.80 \\
Salmonella typhimurium ATCC I4028 & 15.60 \\
Salmonella sp. WS50 & 7.80 \\
Acinetobacter baumanni MDR 44I4 & 250.00 \\
\hline
\end{tabular}

formulation of As-AgNPs for in vivo studies with animal models in our future research investigations.

\section{Conclusion}

This research concludes that As-AgNPs have significant effects on cancer cell lines and microbial pathogens. The simply prepared biologically inspired As-AgNPs were dispersed equally with a small size of 5.6-8.6 nm. The AsAgNPs were potentially active in inhibiting the multiplication of cancer cells in the tested MCF-7 cell lines and exhibited MIC activities with values of $7.80 \mu \mathrm{g} / \mathrm{mL}$ for $E$. coli and $S$. typhi, $31.20 \mu \mathrm{g} / \mathrm{mL}$ for $K$. pneumoniae and $S$. aureus, and $15.60 \mu \mathrm{g} / \mathrm{mL}$ for $S$. typhimurium. In addition, the As-AgNPs displayed antifungal efficiency towards $C$. albicans with an MIC value of $15.60 \mu \mathrm{g} / \mathrm{mL}$. Overall, the green synthesis of As-AgNPs is an effective way to combat cancer cells and microbial pathogens. This is the first report related to the asafoetida-mediated green synthesis of silver nanoparticles and their biological competence activities.

\section{Acknowledgment}

The authors are grateful to the Deanship of Scientific Research, King Saud University for funding through Vice Deanship of Scientific Research Chairs.

\section{Funding}

Research Chairs Program King Saud University Riyadh Saudi Arabia.

\section{Disclosure}

The authors report no conflicts of interest in this work.

\section{References}

1. Amalraj A, Gopi S. Biological activities and medicinal properties of Asafoetida: a review. J Tradit Complement Med. 2017;7:347-359. doi:10.1016/j.jtcme.2016.11.004

2. Mahendra P, Bisht S. Ferula assafoetida: traditional uses and pharmacological activity. Pharmacogn Rev. 2012;6:141-146. doi:10.4103/0973-7847.99948

3. Khazdair MR, Anaeigoudari A, Hashemzehi M, Mohebbati R. Neuroprotective potency of some spice herbs, a literature review. $J$ Tradit Complement Med. 2018;9:98-105. doi:10.1016/j. jtcme.2018.01.002

4. Srinivasan K. Dietary spices as beneficial modulators of lipid profile in conditions of metabolic disorders and diseases. Food Funct. 2013;4:503-521. doi:10.1039/c2fo30249g

5. Schepetkin IA, Kirpotina LN, Khlebnikov AI, Balasubramanian N, Quinn MT. Neutrophil immunomodulatory activity of natural organosulfur compounds. Molecules. 2019;24:eE1809. doi:10.3390/molecules24091809

6. Kiasalari Z, Khalili M, Roghani M, Heidari H, Azizi Y. Antiepileptic and antioxidant effect of hydroalcoholic extract of ferula asafoetida gum on pentylenetetrazole induced kindling in male mice. Basic Clin Neurosci. 2013;4:299-306.

7. Latifi E, Mohammadpour AA, BF H, Nourani H. Antidiabetic and antihyperlipidemic effects of ethanolic Ferula assafoetida oleo-gumresin extract in streptozotocin-induced diabetic wistar rats. Biomed Pharmacother. 2019;110:197-202. doi:10.1016/j.biopha.2018.10.152

8. Wang S, Gao Z, Chen X, et al. The anticoagulant ability of ferulic acid and its applications for improving the blood compatibility of silk fibroin. Biomed Mater. 2008;3:044106. doi:10.1088/1748-6041/3/4/044106

9. Patil D, Shinde S, Kandpile P, Jain AS. Evaluation of antimicrobial activity of asafoetida. Int J Pharm Sci Res. 2015;6:722-727.

10. Afshar FF, Saffarian P, Hosseini HM, Sattarian F, Amin M, Fooladi AA. Antimicrobial effects of Ferula gummosa Boiss gum against extended-spectrum $\beta$-lactamase producing Acinetobacter clinical isolates. Iran J Microbiol. 2016;8:263-273.

11. Beer C, Foldbjerg R, Hayashi Y, Sutherland DS, Autrup H. Toxicity of silver nanoparticles - nanoparticle or silver ion? Toxicol Lett. 2012;208:286-292. doi:10.1016/j.toxlet.2011.11.002

12. Danielle MC, Paresh S, Ray C, Hongtao YU. Molecular toxicity mechanism of nanosilver. J Food Drug Anal. 2014;22:116-127. doi:10.1016/j.jfda.2014.01.010

13. Moradzadeh M, Sadeghnia HR, Mousavi SH, Mahmoodi M, Hosseini A. Ferula gummosa gum induces apoptosis via ROS mechanism in human leukemic cells. Cell Mol Biol. 2017;63:17-22. doi:10.14715/ $\mathrm{cmb} / 2017.63 .11 .4$ 
14. Forouzmand SH, Mousavi SH, Vazifedan V, et al. Synergistic effects of Ferula gummosa and radiotherapy on induction of cytotoxicity in HeLa cell line. Avicenna J Phytomed. 2018;8:439-477.

15. Lee CL, Chiang LC, Cheng LH, et al. $(\mathrm{H}(1) \mathrm{N}(1))$ antiviral and cytotoxic agents from Ferula assa-foetida. $J$ Nat Prod. 2009;72:1568-1572. doi:10.1021/np900158f

16. Iravani S, Korbekandi H, Mirmohammadi SV, Zolfaghari B. Synthesis of silver nanoparticles: chemical, physical and biological methods. Res Pharm Sci. 2014;9:385-406.

17. Sathishkumar M, Sneha K, Won SW, Cho C-W, Kim S, Yun YS. Cinnamon zeylanicum bark extract and powder mediated green synthesis of nano-crystalline silver particles and its bactericidal activity. Colloid Surface B. 2009;73:332-338. doi:10.1016/j. colsurfb.2009.06.005

18. Alfuraydi AA, Devanesan S, Al-Ansari M, AlSalhi MS, Ranjitsingh AJ. Eco-friendly green synthesis of silver nanoparticles from the sesame oil cake and its potential anticancer and antimicrobial activities. J Photochem Photobiol B. 2019;192:83-89. doi:10.1016/j. jphotobiol.2019.01.011

19. Alsalhi MS, Devanesan S, Alfuraydi AA, et al. Green synthesis of silver nanoparticles using Pimpinella anisum seeds: antimicrobial activity and cytotoxicity on human neonatal skin stromal cells and colon cancer cells. Int $J$ Nanomedicine. 2016;11:4439-4449. doi:10.2147/IJN.S113193

20. Devanesan S, AlSalhi MS, Balaji RV, et al. Antimicrobial and cytotoxicity effects of synthesized silver nanoparticles from Punica granatum peel extract. Nanoscale Res Lett. 2018;13:315. doi:10.1186/ s11671-018-2731-y

21. Mosmann T. Rapid colorimetric assay for cellular growth and survival: application to proliferation and cytotoxicity assays. J Immunol Methods. 1983;65:55-63. doi:10.1016/0022-1759(83)90303-4

22. Bonev B, Hooper J, Parisot J. Principles of assessing bacterial susceptibility to antibiotics using the agar diffusion method. $J$ Antimicrob Chemother. 2018;6:1295-1301.

23. Kora AJ, Beedu SR, Jayaraman A. Size-controlled green synthesis of silver nanoparticles mediated by gum ghatti (Anogeissus latifolia) and its biological activity. Org Med Chem Lett. 2017;92:17.

24. Yakout SM, Mostafa AA. A novel green synthesis of silver nanoparticles using soluble starch and its antibacterial activity. Int J Clin Exp Med. 2015;8:3538-3544.

25. Erdogan O, Abbak M, Demirbolat GM, et al. Green synthesis of silver nanoparticles via Cynara scolymus leaf extracts: the characterization, anticancer potential with photodynamic therapy in MCF7 cells. PLoS One. 2019;4:e0216496. doi:10.1371/journal.pone.0216496

26. Demirbolat GM, Altintas L, Yilmaz S, Degim IT. Development of orally applicable, combinatorial drug- loaded nanoparticles for the treatment of Fibrosarcoma. J Pharma Sci. 2018;107:1398-1407. doi:10.1016/j.xphs.2018.01.006

27. Silva CO, Pinho JO, Lopes JM, Almeida AJ, Gaspar MM, Reis C. Current trends in cancer nanotheranostics: metallic, polymeric, and lipid-based systems. Pharmaceuti. 2019;11:30625999. doi:10.3390/ pharmaceutics 11010022

28. Marslin G, Karthik S, Qaisar M, et al. Review: secondary metabolites in the green synthesis of metallic nanoparticles. Materials. 2018;11:940. doi:10.3390/ma11060940

29. Ahamed M, AlSalhi MS, Siddiqui MKJ. Silver nanoparticle applications and human health. Clin Chim Acta. 2010;411:1841-1848. doi:10.1016/j.cca.2010.08.016

30. Farah MA, Ali MA, Chen SM, et al. Silver nanoparticles synthesized from Adenium obesum leaf extract induced DNA damage, apoptosis and autophagy via generation of reactive oxygen species. Colloid Surface B. 2016;141:158-169. doi:10.1016/j.colsurfb.2016.01.027
31. Al-Sheddi ES, Farshori NN, Al-Oqail MM, et al. Anticancer potential of green synthesized silver nanoparticles using extract of Nepeta deflersiana against human cervical cancer cells (HeLA). Bioinorg Chem Appl. 2018;12:9390784.

32. Sánchez-Navarro MC, Ruiz-Torres CA, Niño-Martínez N, et al. Cytotoxic and bactericidal effect of silver nanoparticles obtained by green synthesis method using annona muricata aqueous extract and functionalized with 5-fluorouracil. Bioinorg Chem Appl. 2018;2018:1-8. doi:10.1155/2018/6506381.

33. Mameneh R, Shafiei M, Aidy A, Karimi E, Badakhsh B, Abbasi N. Toxicity study of silver nanoparticles synthesized from aqueous flower extract of Scrophularia striata on MCF-7 human breast cancer cell line. Phcog Mag. 2019;15:66-72. doi:10.4103/pm.pm_78_18

34. Sonia S, Venkatesan K. Green synthesis of silver nanoparticles from aqueous leaf extract of pomegranate (Punica granatum) and their anticancer activity on human cervical cancer cells. Adv Nat Sci Nanosci Nanotechnol. 2018;9:02501.

35. Devanesan S, AlSalhi MS, Vishnubalaji R, et al. Rapid biological synthesis of silver nanoparticles using plant seed extracts and their cytotoxicity on colorectal cancer cell lines. J Clust Sci. 2017;28:595605. doi:10.1007/s10876-016-1134-4

36. Khorrami S, Zarrabi A, Khaleghi M, Danaei M, Mozafari MR. Selective cytotoxicity of green synthesized silver nanoparticles against the MCF-7 tumor cell line and their enhanced antioxidant and antimicrobial properties. Int J Nanomed. 2018;13:8013-8024. doi:10.2147/IJN.S189295

37. Galati G, O'Brien PJ. Potential toxicity of flavonoids and other dietary phenolics: significance for their chemopreventive and anticancer properties. Free Radic Biol Med. 2004;37:287-303. doi:10.1016/j. freeradbiomed.2004.04.034

38. Madunić J, Madunić IV, Gajski G, Popić J, Garaj-Vrhovac V. Apigenin: a dietary flavonoid with diverse anticancer properties. Cancer Lett. 2018;413:11-22. doi:10.1016/j.canlet.2017.10.041

39. Park EJ, Yi J, Kim Y, Choi K, Park K. Silver nanoparticles induce cytotoxicity by a Trojan-horse type mechanism. Toxicol in Vitro. 2010;24:872-878. doi:10.1016/j.tiv.2009.12.001

40. Sangeetha J, Sandhya J, John P. Biosynthesis and functionalization of silver nanoparticles using Nigellasativa, dioscorea alata and Ferula asafoetida. Sci Adv Mater. 2014;6:1681-1690. doi:10.1166/sam.2014.1991

41. Mohammed AE, Al-Qahtani A, Al-Mutairi A, Al-Shamri B, Aabed K. Antibacterial and cytotoxic potential of biosynthesized silver nanoparticles by some plant extracts. Nanomaterials. 2018;8:382. doi:10.3390/nano8060382

42. Zheng K, Setyawati MI, Leong DT, Xie J. Antimicrobial silver nanomaterials. Coord Chem Rev. 2018;357:1-17. doi:10.1016/j. ccr.2017.11.019

43. Manivasagan P, Venkatesan J, Senthilkumar K, Sivakumar K, Kim S. Biosynthesis, antimicrobial and cytotoxic effect of silver nanoparticles using a novel Nocardiopsis sp. MBRC Bio Med Res Int. 2013;287638.

44. Zheng K, Setyawati MI, Leong DT, Jianping Xie J. Antimicrobial gold nanoclusters. ACS Nano. 2017;11:6904-6910. doi:10.1021/ acsnano.7b02035

45. Sondi I, Salopek-Sondi B. Silver nanoparticles as antimicrobial agent: a case study on $E$. coli as a model for gram-negative bacteria. J Colloid Interf Sci. 2004;275:177e82. doi:10.1016/j.jcis.2004.02.012

46. Rai M, Yadav A, Gade A. Silver nanoparticles as a new generation of antimicrobials. Biotechnol Adv. 2009;27:76-83. doi:10.1016/j. biotechadv.2008.09.002

47. Pal SI, Tak YK, Song JM. Does the antibacterial activity of silver nanoparticles depend on the shape of the nanoparticle? A study of the gram-negative bacterium Escherichia coli. Appl Environ Microbiol. 2007;73:1712-1720. doi:10.1128/AEM.02218-06 


\section{Publish your work in this journal}

The International Journal of Nanomedicine is an international, peerreviewed journal focusing on the application of nanotechnology in diagnostics, therapeutics, and drug delivery systems throughout the biomedical field. This journal is indexed on PubMed Central, MedLine, CAS, SciSearch ${ }^{\circledR}$, Current Contents ${ }^{\circledR} /$ Clinical Medicine,
Journal Citation Reports/Science Edition, EMBase, Scopus and the Elsevier Bibliographic databases. The manuscript management system is completely online and includes a very quick and fair peer-review system, which is all easy to use. Visit http://www.dovepress.com/ testimonials.php to read real quotes from published authors. 